\title{
Cauixi em cerâmica arqueológica da região de Lagoa Santa, Minas Gerais: inclusão de esponjas processadas ou exploração de depósitos sedimentares com espículas? \\ Cauixi sponge in archaeological pottery from the Lagoa Santa region, Minas Gerais, Brazil: inclusion of processed sponges or exploitation of sedimentary deposits with spicules?
}

\author{
Igor Morais Mariano Rodrigues', Cecilia Volkmer-Ribeiro", Vanessa de Souza Machado'II \\ Universidade Federal de Minas Gerais. Belo Horizonte, Minas Gerais, Brasil \\ "Fundação Zoobotânica do Rio Grande do Sul. Porto Alegre, Rio Grande do Sul, Brasil \\ IIIFaculdade Monteiro Lobato. Porto Alegre, Rio Grande do Sul, Brasil
}

\begin{abstract}
Resumo: Este artigo apresenta a primeira identificação do cauixi em cerâmica arqueológica na região de Lagoa Santa, Minas Gerais. Trata-se de um estudo zooarqueológico que aborda as escolhas pretéritas feitas pelos ameríndios no que tange à presença de espículas de esponjas dulcícolas no processo de produção cerâmica. A partir dos elementos faunísticos detectados na coleção do sítio Vereda III, juntamente com informações obtidas de registros etnográficos e de pesquisas arqueológicas que tratam da presença do cauixi em cerâmica, é discutido se a presença desse elemento no material é fruto de coleta de esponjas dulcícolas, preparo e inclusão na pasta, ou se ele advém da exploração de depósitos sedimentares com espículas. $\bigcirc$ trabalho aponta para uma necessária revisão do material cerâmico arqueológico da tradição Aratu-Sapucaí em Minas Gerais, em que a identificação do cauixi e a sua proveniência devem ser consideradas.
\end{abstract}

Palavras-chave: Zooarqueologia. Cauixi. Cerâmica arqueológica. Tradição Aratu-Sapucaí. Lagoa Santa.

Abstract: This article presents the first identification of cauixi sponge material in archaeological pottery from the Lagoa Santa region, Minas Gerais, Brazil. This zooarchaeological study addresses whether the presence of spicules of freshwater sponges in this pottery was a conscious choice on behalf of ancient potters. Based on faunal elements detected in the collection of the Vereda III site and information obtained from ethnographic records and archaeological research on the presence of cauixi in pottery, we discuss whetherits presence in the material results from the inclusion of processed freshwater sponges in the clay or if it derives from the exploitation of sedimentary deposits with spicules. As one of the outcomes, this articlepoints to a necessary revision of the archaeological pottery material of the Aratu-Sapucaí tradition in Minas Gerais where the identification of cauixi and its origin should both be considered.

Keywords: Zooarchaeology. Cauixi sponge. Archaeological pottery. Aratu-Sapucaí tradition. Lagoa Santa.

RODRIGUES, Igor Morais Mariano; VOLKMER-RIBEIRO, Cecilia; MACHADO, Vanessa de Souza. Cauixi em cerâmica arqueológica da região de Lagoa Santa, Minas Gerais: inclusão de esponjas processadas ou exploração de depósitos sedimentares com espículas? Boletim do Museu Paraense Emílio Goeldi. Ciências Humanas, v. 12, n. 1, p. 85-100, jan.-abr. 2017. DOI: http://dx.doi.org/10.1590/1981. 81222017000100005.

Autor para correspondência: Igor Morais Mariano Rodrigues. Rua Gustavo da Silveira, 1035 - Santa Inês. Belo Horizonte, MG, Brasil. CEP 31080-010 (igor_mmrodrigues@hotmail.com).

Recebido em 30/03/2016

Aprovado em 15/07/2016

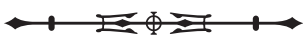




\section{INTRODUÇÃO}

Cauixi, termo de origem tupi-guarani que significa "mãe da coceira"1 (Volkmer-Ribeiro; Viana, 2006, p. 311), é utilizado na Arqueologia em referência às espículas de esponjas dulcícolas encontradas nos fragmentos cerâmicos. Esse tipo de fauna é abundante na região neotropical, particularmente no Brasil, habitando lagoas ou margens de rios, onde fica presa à vegetação inundada (VolkmerRibeiro; Pauls, 2000; Volkmer-Ribeiro; Viana, 2006). O contato com grande quantidade de espículas pode provocar diversas espongioses, como reações alérgicas, inflamações (Magalhães et al., 2011), lesões oculares e até cegueira (Volkmer-Ribeiro et al., 2006; Cruz et al., 2013).

Essas espículas têm sido identificadas, recorrentemente, em cerâmicas arqueológicas amazônicas, sendo um dos antiplásticos considerados diagnósticos na definição de tradições e fases diversas. Fora da Amazônia também há registros de cauixi em cerâmica arqueológica, na região Centro-Oeste, como em Mato Grosso, Mato Grosso do Sul (Wüst, 1991; Volkmer-Ribeiro; Viana, 2006; Migliacio, 2006; Volkmer-Ribeiro; Gomes, 2006) e Goiás (Oliveira, 2009, 2014; Viana et al., 2011).

Este artigo, inserido no âmbito da zooarqueologia (Lima, 1989), apresenta a primeira identificação do cauixi em cerâmica arqueológica em Minas Gerais, compreendendo uma variedade de cinco espécies de esponjas. A partir dos elementos faunísticos detectados no estudo, juntamente com informações obtidas de registros etnográficos e pesquisas arqueológicas que tratam da presença do cauixi em cerâmica, são abordadas as escolhas pretéritas feitas pelos ameríndios no que tange à presença de espículas de esponjas dulcícolas no processo de produção cerâmica. Mais especificamente, discute-se se o elemento biosilicoso observado no material cerâmico da coleção do sítio Vereda III, região de Lagoa Santa, Minas Gerais, é fruto de coleta de esponjas dulcícolas, preparo e inclusão na pasta, ou se ele advém da exploração de depósitos sedimentares com espículas.

\section{CAUIXI EM CERÂMICA: INFORMAÇÕES ETNOGRÁFICAS E ARQUEOLÓGICAS}

Há poucos registros etnográficos sobre a utilização do cauixi na produção cerâmica de grupos ameríndios nas terras baixas sul-americanas. De acordo com o mapeamento de zonas de mistura artificial de espículas de esponja de água doce no barro de oleiro, elaborado em 1937 pelo zoólogo alemão Walther Arndt e reproduzido no artigo de Moraes (1944), a ocorrência de cauixi em cerâmica foi registrada no alto rio Orinoco; na foz do rio Xingu; na foz do Tapajós; em tributários do rio Madeira, tais como na confluência dos rios Mamoré e Guaporé, e no baixo curso do rio Ji-Paraná; no médio curso do rio Araguaia; e, mais ao sul, no médio e no baixo curso do rio Uruguai. Todavia, não há informações a respeito dos grupos indígenas que utilizavam esse recurso. Tampouco há dados sobre sua forma de aquisição: se através de coleta de esponjas ou exploração de depósitos sedimentares com espículas.

Willey (1986) menciona que o uso de espongiários na cerâmica é feito pelos grupos Karajá e Canichana, respectivamente, no Brasil e na Amazônia boliviana. A utilização do cauixi como tempero, feita pelos Karajá na região do Araguaia, também é mencionada em outros trabalhos (Moraes, 1944; Machado, 1947 apud Oliveira, 2014; Hilbert, 1955), embora existam informações de que, posteriormente, passaram a adotar o caraipé (Wüst, 1975; Lima, 1986). De acordo com um levantamento de informações etnográficas sobre cerâmica indígena no Brasil (Lima, 1986), entre os 64 grupos que até aquele momento faziam cerâmica, somente dois - os Txapakúra, na região do Guaporé, e os Waujá, no alto Xingu coletavam espongiários para utilizá-los como tempero, após processamento no fogo e peneiramento. Segundo Barcelos Neto (2005-2006), para os Waujá do alto Xingu, a resistência de panelas e torradores depende da quantidade exata de cinzas com espículas, resultantes da queima de

\footnotetext{
Segundo Volkmer-Ribeiro e Viana (2006, p. 311), cauixi ou cauxi advém de cauí e cy, que, respectivamente, significam coceira e mãe.
} 
esponjas ${ }^{2}$, adicionadas à argila. Se houver excesso de cinzas com espículas, a superfície de um recipiente poderá apresentar pequenas rachaduras, provocadas por uma rápida secagem. Por outro lado, se a quantidade misturada for inferior à ideal, a peça não suportará a pressão nas etapas de raspagem e de lixamento. A mistura ideal é percebida por eles através do tato, "a plasticidade da argila pura (fria por definição) torna-se 'quente', ou seja, adquire a plasticidade ideal para modelagem" (Barcelos Neto, 2005-2006, p. 366).

Na região de Oriximiná, Pará, Hilbert (1955) observou que grupos caboclos ${ }^{3}$ reconheciam que o processo de secagem e de queima de cerâmicas com cauixi era mais seguro em relação às temperadas com caraipé, posto que os potes com cauixi queimam mais uniformemente, além de serem mais sólidos. Mesmo assim, esses artesãos preferiam o uso do segundo tipo de tempero, pois, segundo eles, a preparação da pasta com o cauixi provocava inchaço nas mãos e, caso se alimentassem em potes contenedores de espículas, havia a possibilidade de desarranjos estomacais.

Na década de 1940, Luciano Jacques de Moraes observou a utilização de espongilitos ${ }^{4}$, por grupos não indígenas, na fabricação de telhas, tijolos, entre outros objetos de cerâmica na região do Triângulo Mineiro (Moraes, 1944). Os oleiros da região usavam jazidas locais por reconhecerem a boa qualidade do material resultante da produção. Essas jazidas eram conhecidas como 'pó de mico' ou 'pinico's.

O reconhecimento de qualidades acerca do uso de esponjas ou de jazidas com espículas para a produção de cerâmica, por parte dos oleiros em geral aqui referenciados, é corroborado por alguns autores, que indicam a possibilidade de a presença de cauixi em recipientes cerâmicos fornecer resistência aos choques térmico e mecânico e aumentar a porosidade, além de proporcionar leveza aos potes (Machado, 2005-2006; Volkmer-Ribeiro; Viana, 2006). Em pesquisa comparativa recente (Natalio et al., 2015), a reprodução de cerâmicas em laboratório feitas com a técnica do rolete, contendo diferentes inclusões de areia, fibras de vidro e espículas de esponjas, indicou o cauixi como o tempero que melhor evita a retração excessiva da argila, além de dificultar a propagação de rachaduras na cerâmica e aumentar significativamente a rigidez do material.

Deixando de lado essas características especíicas do uso do cauixi na cerâmica, por meio das informações levantadas, nota-se que a presença desse elemento no material cerâmico advém da coleta de esponjas, sobretudo para os casos de grupos ameríndios e 'caboclos'. A aquisição do espongiário dulcícola inclusive é feita através do mergulho pelos Waujá (Barcelos Neto, 2005-2006). Por outro lado, a exploração de jazidas de argila com espículas ou a exploração de espongilitos poderá ser a possível explicação para a presença de cauixi em algumas cerâmicas, porém não há registros etnográficos de que esta prática tenha sido adotada por grupos indígenas.

No caso das cerâmicas arqueológicas, de acordo com a bibliografia, não há evidências contundentes de exploração pré-colonial de jazidas com espículas de esponjas, ainda que esta possibilidade não seja descartada por alguns autores (Volkmer-Ribeiro; Viana, 2006; Oliveira, 2014). As únicas evidências arqueológicas disponíveis correspondem à coleta de esponjas, ao processamento por meio da queima e à inclusão na pasta argilosa, visto a observação de espículas trituradas e com marcas de exposição ao fogo (Volkmer-Ribeiro; Gomes, 2006; Volkmer-Ribeiro; Viana, 2006).

2 Os Waujá denominam de akukutai os espongiários lacustres, já as cinzas resultantes da queima dos espongiários são chamadas de akukupe (Barcelos Neto, 2005-2006, p. 366).

3 Utiliza-se o termo "caboclo" reproduzindo o que foi empregado por Hilbert (1955). Todavia, sabe-se que esse termo apresenta um conjunto denso de significados, incluindo sentidos pejorativos, que são fruto da ocupação histórica europeia da Amazônia. Para maiores detalhes sobre o assunto, ver Lima (1999).

4 Espongilitos são, em linhas gerais, rochas sedimentares inconsolidadas, compostas por espículas de esponjas de água doce, depositadas junto com argila e areia.

5 Do verbo pinicar. 
Destaca-se que estudos zooarqueológicos são fundamentais para o avanço da discussão sobre a proveniência das espículas observadas no material arqueológico, pois contribuem para a identificação das espécies de esponjas dulcícolas, assim como informam sobre seu habitat (Gomes, 2002; Volkmer-Ribeiro; Viana, 2006). Essa abordagem possibilita inferências sobre os prováveis lugares de coleta de determinadas espécies, bem como o tratamento dado às esponjas antes de sua inclusão na pasta (Volkmer-Ribeiro; Gomes, 2006; VolkmerRibeiro; Viana, 2006). A identificação das espécies, bem como o habitat ou, no caso de depósitos sedimentares com espículas, quando possível, o reconhecimento do período de vivência das espécies tornam-se potentes ferramentas para inferir a proveniência de exemplares de esponjas, cujas espículas foram identificadas no material arqueológico.

\section{ESPÍCULAS DE ESPONJAS DE ÁGUA DOCE}

As esponjas dulcícolas apresentam corpo formado por esqueleto composto por diversas espículas silicosas, ligadas por espongina, elementos que contribuem para a sustentação e o suporte de comunidades de células que agem nos processos de filtração, clonagem e reprodução dos indivíduos.

Oriundas de esponjas marinhas, paulatinamente adaptadas ao ambiente de água doce ao longo de milênios, as esponjas dulcícolas são seres filtradores e sésseis, que habitam desde os fundos rochosos de rios e suas margens até lagoas, estando presas nas rochas, na vegetação marginal inundada ou nas macrófitas (Volkmer-Ribeiro; Pauls, 2000). Fatores como disponibilidade de sílica e nutrientes, temperatura, iluminação, oxigenação e reduzida ou ausente turbidez das águas são fundamentais para sua ocorrência e proliferação. Em função disso, esponjas podem ser usadas como indicadores de condições ambientais, assim como jazidas com espículas podem ser usadas também para estudos paleoambientais e paleoclimáticos (Almeida et al., 2009; Machado et al., 2014).

O estudo taxonômico das espécies é feito por meio da morfologia da estrutura esqueletal, cujos componentes espiculares, de acordo com Volkmer-Ribeiro e Viana (2006), podem ser categorizados em: 1) megascleras: espículas maiores, que compõem o esqueleto das esponjas; 2) microscleras: espículas menores, geralmente encontradas na superfície da esponja; 3) gemoscleras: revestem os corpúsculos esféricos da reprodução assexuada (clonagem), denominados 'gêmulas'; é a espícula que oferece possibilidade mais segura para identificação de espécie.

\section{ESPONGILITOS EM MINAS GERAIS}

Espongilitos são rochas sedimentares inconsolidadas, compostas predominantemente $(+50 \%)$ por espículas silicosas, oriundas de espongiários de ambiente lacustre, de águas doces e calmas. Essas rochas geralmente estão associadas a argila, areia, matéria orgânica e, em alguns casos, carapaças de diatomáceas (Volkmer-Ribeiro; Motta, 1995; Almeida et al., 2009, 2011).

No Brasil, há duas áreas conhecidas de formaç̧ão de espongilitos. Uma delas se localiza na região Nordeste, atrás de cinturões de dunas. A outra, chamada de província de espongilitos, compreende o Triângulo Mineiro, o norte de São Paulo, o nordeste do Mato Grosso do Sul e o sudeste de Goiás (Volkmer-Ribeiro; Motta, 1995; Volkmer-Ribeiro et al., 1998). Essas duas áreas diferem entre si pelo fato de que, na primeira, as espículas ocorrem junto aos diatomitos, enquanto a segunda corresponde a "verdadeiros espongilitos" (Volkmer-Ribeiro et al., 1998). Atualmente, a área da mencionada província foi ampliada até o noroeste de Minas Gerais (Almeida et al., 2009).

O primeiro registro da existência de espongilitos no Triângulo Mineiro se deu durante o decênio de 1940, no município de Conceição das Alagoas, Minas Gerais, em pelo menos sete lagoas sazonais (Moraes, 1944). De modo geral, as lagoas apresentam de 600 a 800 m de comprimento, por 400 a 500 m de largura, sendo que o espongilito ocorre entre 3 e $4 \mathrm{~m}$ de profundidade, com espessuras que variam de 0,50 a mais de $1 \mathrm{~m}$. Na lagoa de Dourados, observou-se que o espongilito estava assentado sobre arenitos cretáceos (Moraes, 1944). Moraes também 
registrou notícias de outras lagoas localizadas na margem esquerda do rio Uberaba.

No decênio de 1990, novas pesquisas foram feitas na região do Triângulo Mineiro, abrangendo os municípios de Conceição das Alagoas e Santa Vitória (Volkmer-Ribeiro; Motta, 1995). No primeiro município, foram alvos de pesquisa a lagoa Sem Noite, a lagoa da Olaria dos Datos e o brejo da fazenda Boa Vista. Em Santa Vitória, foi estudada a lagoa do Degredo. Todas as lagoas apresentaram espongilito, além de sedimentos diversos, com teor reduzido de espículas. Já as análises no brejo da fazenda Boa Vista revelaram que o material não corresponde, de fato, a um espongilito, e, sim, a um depósito de argila, areia e turfa, com espículas de esponjas (Volkmer-Ribeiro; Motta, 1995). A camada superficial desse depósito é mais escura em relação às camadas inferiores, de coloração acinzentada. Nas lagoas com presença de espongilitos, em linhas gerais, as camadas superficiais de turfa com espículas são mais escuras, sendo que as camadas inferiores gradativamente apresentam quantidade menor de turfa, com coloração cinza e acinzentada-clara, com porções quase brancas. O primeiro trabalho a apresentar datações para essas jazidas com espongilitos (Almeida et al., 2009) indicou idade entre o Pleistoceno tardio e o Holoceno, confirmando a previsão de Volkmer-Ribeiro e Motta (1995), de que os sistemas lênticos em que essas comunidades de esponjas viveram seriam holocênicos e, ainda, com clima distinto do atual.

$\mathrm{Na}$ província de espongilitos, seis espécies de esponjas foram responsáveis pela produção dos depósitos: Metania spinata, Dosilia pydanieli, Trochospongilla variabilis, Radiospongilla amazonensis, Corvomeyenia thumi e Heterorotula fistula (Volkmer-Ribeiro; Motta, 1995; Volkmer-Ribeiro et al., 1998). A formação do espongilito, bem como das jazidas com espículas, nas lagoas da província se deu preteritamente, em função de apresentar clima distinto ao do cerrado atual, com chuvas mais frequentes abastecendo as lagoas com sílica, elemento crucial para a formação das espículas (Almeida et al., 2009).
Machado et al. (2014) ampliaram a lista com Corvoheteromeyenia australis para essas comunidades de esponjas, que tipificam lagoas atuais do bioma cerrado. Foram ainda detectadas no depósito espongilítico do paleolago Cemitério, em Catalão, Goiás (Machado et al., 2014), como raras e provenientes de efluente lótico espículas das espécies Corvospongilla seckti, Oncosclera navicella e Eunapius fragilis. Este depósito, até então, é o mais antigo do Brasil Central, datado de $27500 \pm 4000$ anos AP até $51780 \pm 400$ anos AP, por ${ }^{14} \mathrm{C}$.

Pesquisas sobre espongilitos e sobre sedimentos com algum teor de espículas associadas em lagos naturais em Minas Gerais ainda são escassas (Almeida et al., 2009), não havendo, até o momento, pesquisas na região de Lagoa Santa. Não obstante, as informações expostas nesta seção são importantes para pensar a presença de cauixi na cerâmica arqueológica do sítio Vereda III. No mínimo, essas pesquisas evidenciam a disponibilidade de cauixi na forma de depósitos sedimentares com espículas em Minas Gerais, ocorrendo em lagoas ou brejos, em uma profundidade que não ultrapassa os quatro metros. Ademais, os dados indicam as idades de formaçãa dos depósitos, bem como a coloração dos sedimentos.

\section{MÉTODOS E TÉCNICAS DE RECONHECIMENTO DE ESPÍCULAS E IDENTIFICAÇÃO DE ESPÉCIES}

Pesquisadores que trabalham com cerâmicas arqueológicas percebem, durante o manuseio, a presença de cauixi na pasta através das típicas coceiras. Nas cerâmicas da coleção do sítio Vereda III, entretanto, o cauixi não provocou comichões. Além disso, sua ocorrência era inesperada, já que não há referência alguma sobre a existência desse tipo de antiplástico/tempero em cerâmica arqueológica no território mineiro.

As espículas foram identificadas, em um primeiro momento, com a utilização de estereoscópio binocular, com aumento de até 40x, e com microscópio ótico. A prova visual confirmatória só foi obtida com o estudo ao Microscópio 
Eletrônico de Varredura (MEV) da área interna da parede de um fragmento manualmente seccionado (Figura 1). No segundo momento, o procedimento iniciou-se com uma raspagem em amostras de fragmentos cerâmicos. O pó resultante foi colocado em tubo de ensaio e fervido com ácido nítrico, para retirada dos resíduos orgânicos. Seguiramse lavagens em água corrente e centrifugação. O pó silicoso depositado no tubo foi agitado, para entrar em suspensão na água, sendo pipetado sobre lâmina e posto para secar.
Depois de seco, foi coberto com Entellan e uma lamínula, para ser estudado em microscópio ótico, possibilitando a classificação taxonômica das espécies de esponjas pelas espículas presentes (Volkmer-Ribeiro; Gomes, 2006).

\section{A PRESENÇA DE CAUIXI NA COLEÇÃO DO SÍTIO VEREDA III}

O cauixi está presente em vestígios cerâmicos do sítio Vereda III, tais como em fragmentos de potes,

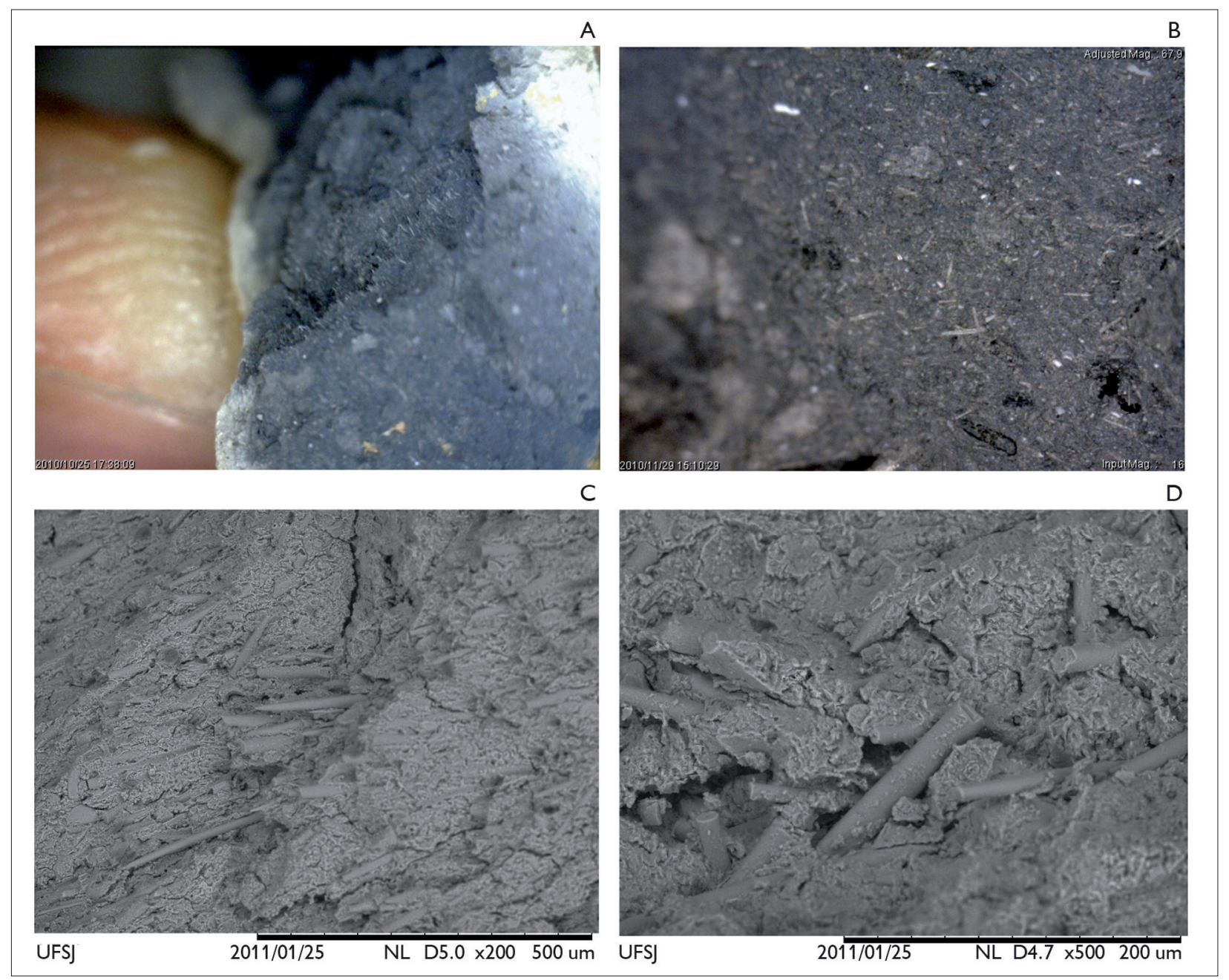

Figura 1. Registro feito com microscópio ótico de fragmento de cerâmica do sítio Vereda III (A e B) e feito com microscopia eletrônica de varredura (C e D): A) os pequenos 'fios' correspondem às espículas - observar a inclinação do fragmento necessária para visualização: B) os pequenos 'fios' correspondem às espículas (aumento de 60x); C) os 'tubos' compridos correspondem às espículas (aumento de 200x); D) os 'tubos' compridos correspondem às espículas (aumento de 500x). Fotos (A e B): Igor Rodrigues. Imagens de MEV (C e D): Departamento de Engenharia Mecânica da Universidade Federal de São João del-Rei (UFSJ).

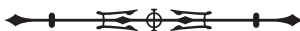


em rodelas de tortual de fuso e em uma 'bolota' de argila não queimada, com aproximadamente $17 \mathrm{~cm}$ de comprimento por $12 \mathrm{~cm}$ de largura, encontrada in situ na escavação (Rodrigues, 2011). Duas das três categorias de pastas discriminadas nos artefatos cerâmicos identificados apresentaram espículas, contudo, em proporções diferentes.

As categorias de pasta foram estabelecidas com base na análise quantitativa, com observação dos antiplásticos/ temperos, sua quantidade (frequência) ${ }^{6}$ e granulometria, com o uso de estereoscópio binocular com aumento de até 40x. A análise compreendeu 1.771 fragmentos cerâmicos, dos quais $58 \%$ foram usados na remontagem parcial de 24 potes (Rodrigues, 2011). Complementarmente, realizaram-se análises qualitativas, em exemplares de cada tipo de pasta, por meio de difratometria de raios $X$ (DFRX) e Microscopia Eletrônica de Varredura (MEV) 7 . As características de cada tipo de pasta estão informadas no Quadro 1.
As três categorias de pasta podem ser assim resumidas: pasta $A$ (muito cauixi + pequenos cacos moídos); pasta B (pouco cauixi + grandes cacos moídos); pasta C (mineral). Como se nota, o tipo de pasta C é completamente diferente dos demais, já os tipos $A$ e $B$ são semelhantes quanto aos elementos constituintes do conjunto de antiplástico/ tempero. Não obstante, esses dois tipos de pasta diferem entre si pela presença de loveringita e carbono no tipo A, além de diferenças significativas em relação ao tamanho e proporção de caco moído e cauixi que ambos apresentam (Figuras 2 e 3). Os dois tipos também diferem pelo fato de a pasta $A$ ser um pouco mais porosa do que a pasta B (Quadro 1). Em todo caso, o que mais se destaca na diferença entre essas pastas é a maior quantidade de caco moído grande (> $3 \mathrm{~mm}$ ) em fragmentos da categoria B e maior quantidade de cauixi na categoria $A$.

A 'bolota' de argila encontrada durante as escavações é uma fonte arqueológica importante para refletir sobre as possibilidades de proveniência das espículas de esponjas

Quadro 1. Resumo das características das três categorias de pasta.

\begin{tabular}{|c|c|c|c|c|c|}
\hline $\begin{array}{l}\text { Tipo de } \\
\text { pasta }\end{array}$ & $\begin{array}{l}\text { Antiplásticos/temperos } \\
\text { constituintes da pasta }\end{array}$ & $\begin{array}{l}\text { Granulometria dos } \\
\text { elementos não plásticos }\end{array}$ & $\begin{array}{l}\text { Quantidade de } \\
\text { elementos não plásticos }\end{array}$ & $\begin{array}{c}\text { Elementos apontados } \\
\text { por DFRX }\end{array}$ & $\begin{array}{l}\text { Porosidade } \\
\text { da pasta }\end{array}$ \\
\hline A & $\begin{array}{l}\text { Caco moído }<3 \text { mm; } \\
\text { cauixi; matéria orgânica; } \\
\text { quartzo }<3 \text { mm; argila } \\
\text { vermelha; caco moído } \geq \\
3 \text { mm; quartzo } \geq 3 \text { mm }\end{array}$ & Fina $(<3 \mathrm{~mm})$ & $5 \%$ & $\begin{array}{l}\text { Óxido de sílica; carbono; } \\
\text { óxido de alumínio; } \\
\text { gismondina; loveringita }\end{array}$ & $24 \%$ \\
\hline B & $\begin{array}{c}\text { Caco moído }<3 \text { mm; } \\
\text { quartzo }<3 \mathrm{~mm} \text {; caco } \\
\text { moído } \geq 3 \mathrm{~mm} \text {; matéria } \\
\text { orgânica; cauixi; argila } \\
\text { vermelha; quartzo } \geq 3 \mathrm{~mm}\end{array}$ & $\begin{array}{c}\text { Fina e grossa }(<3 \mathrm{~mm} \\
\mathrm{e} \geq 3 \mathrm{~mm})\end{array}$ & 5 a $10 \%$ & $\begin{array}{l}\text { Óxido de sílica; óxido de } \\
\text { alumínio; gismondina }\end{array}$ & $19 \%$ \\
\hline C & $\begin{array}{c}\text { Quartzo }<3 \text { mm; } \\
\text { feldspato; matéria orgânica; } \\
\text { quartzo } \geq 3 \text { mm }\end{array}$ & Fina $(<3 \mathrm{~mm})$ & 20 a $30 \%$ & $\begin{array}{c}\text { Óxido de sílica; } \\
\text { tazheranita; gismondina; } \\
\text { silicato de sódio; alumínio } \\
\text { hidratado; halloysita }\end{array}$ & $15 \%$ \\
\hline
\end{tabular}

6 Para a definição da quantidade (frequência) dos elementos não plásticos, adaptou-se o esquema de Orton et al. (1997), cuja menor partícula quantificada mede $0,5 \mathrm{~mm}$. Deste modo, não foram consideradas para frequência as espículas de cauixi, na medida em que a maior espícula identificada tem aproximadamente $1 / 4$ de $\mathrm{mm}$ de comprimento.

7 As análises de DFRX e MEV foram realizadas no Departamento de Ciências Naturais, na área de Física e Química de Materiais, e no Departamento de Engenharia Mecânica, da Universidade Federal de São João del-Rei (UFSJ).

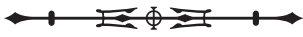




\section{Antiplástico/Tempero (pasta A)}

$\begin{array}{ll}\text { Caco moído }<3 \mathrm{~mm} & \text { Cauixi } \\ \text { Matéria orgânica } & \text { Quartzo }<3 \mathrm{~mm} \\ \text { Argila vermelha } & \text { Caco moído }>3 \mathrm{~mm} \\ \text { Quartzo }>3 \mathrm{~mm} & \end{array}$

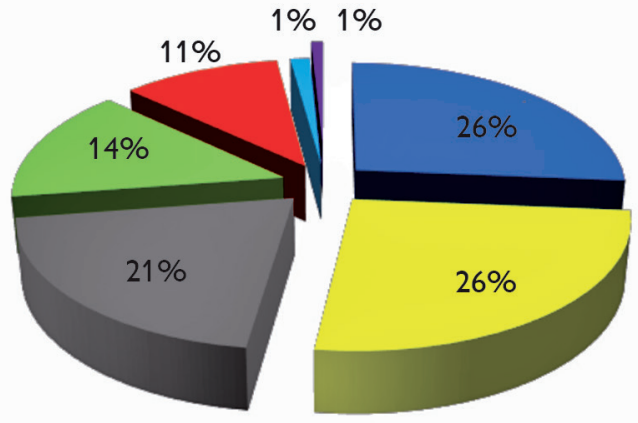

Figura 2. Porcentagem relativa dos elementos antiplásticos/temperos constituintes da pasta $A$.

identificadas em cerâmicas feitas com os tipos de pastas A e B. Nela, por DFRX, foram identificados óxido de sílica e gismondina, elementos também encontrados nas categorias de pastas A e B. Assim como nestas, há quartzo, caco moído e cauixi na 'bolota'. A correspondência entre os seus constituintes e os tipos de pasta A (muito cauixi + pequenos cacos moídos) e pasta B (pouco cauixi + grandes cacos moídos) pode indicar que a 'bolota' é um testemunho de matéria-prima utilizada na produção desses dois tipos de pasta. Isso não significa dizer que uma única 'bolota' serviu para a produção de dois tipos de pasta. Visto que ela apresenta antiplásticos/temperos, entre outros elementos apontados por DFRX, correspondentes aos observados nas categorias de pasta A e B, entende-se que é um vestígio de receita para a produção de pastas argilosas temperadas, que pode ser tanto o tipo A quanto o tipo B. Outras implicações da semelhança entre os seus constituintes e esses dois tipos de pasta, bem como das características das espículas identificadas no material arqueológico em estudo, serão abordadas na seção seguinte. Além disso, discutir-se-ão as hipóteses explicativas da presença do cauixi no material.

\section{Antiplástico/Tempero (pasta B)}
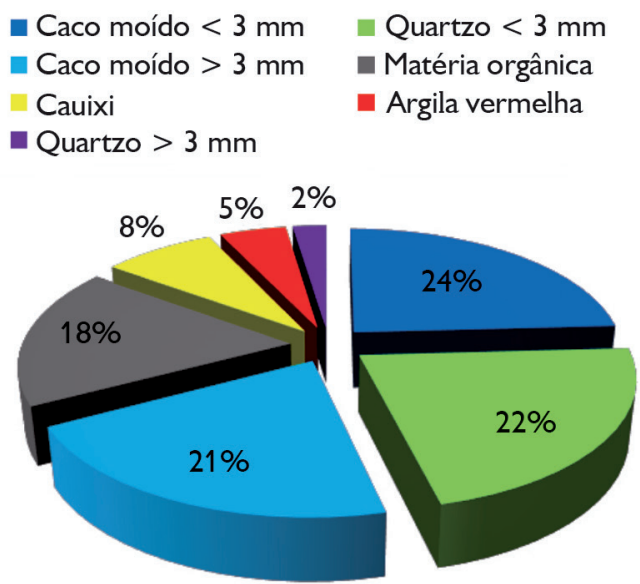

Figura 3. Porcentagem relativa dos elementos antiplásticos/temperos constituintes da pasta B.

\section{A PROVENIÊNCIA DO CAUIXI NA COLEÇÃO DO SÍTIO VEREDA III}

Pelo fato de não estar queimada, isto é, fundida, a 'bolota' possibilitou a identificação de dois tipos de argila, um vermelho e outro cinza, com partes alaranjadas entre eles, que, provavelmente, correspondem à mistura das duas argilas. As análises de MEV na 'bolota' de argila não queimada permitiram notar que as espículas concentram-se somente na argila cinza (Figura 4). Isto é um forte indicativo de que esponjas não foram coletadas, processadas e adicionadas à pasta, mas que espículas já estavam presentes na própria argila coletada. Caso fossem adicionadas na pasta como um todo, como foi o caso do caco moído, não faria sentido estarem presentes, exclusivamente, em uma das argilas, a menos que fossem adicionadas somente na argila cinza, de modo a preparar uma pasta específica, que seria posteriormente misturada à argila vermelha. Isso certamente dificultaria ainda mais a homogeneização das espículas na pasta como um todo. Acredita-se que a homogeneização deveria ser desejada, visto a capacidade de melhora na queima de um pote que o cauixi oferece, conforme informações obtidas por Hilbert (1955).

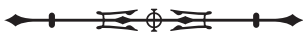



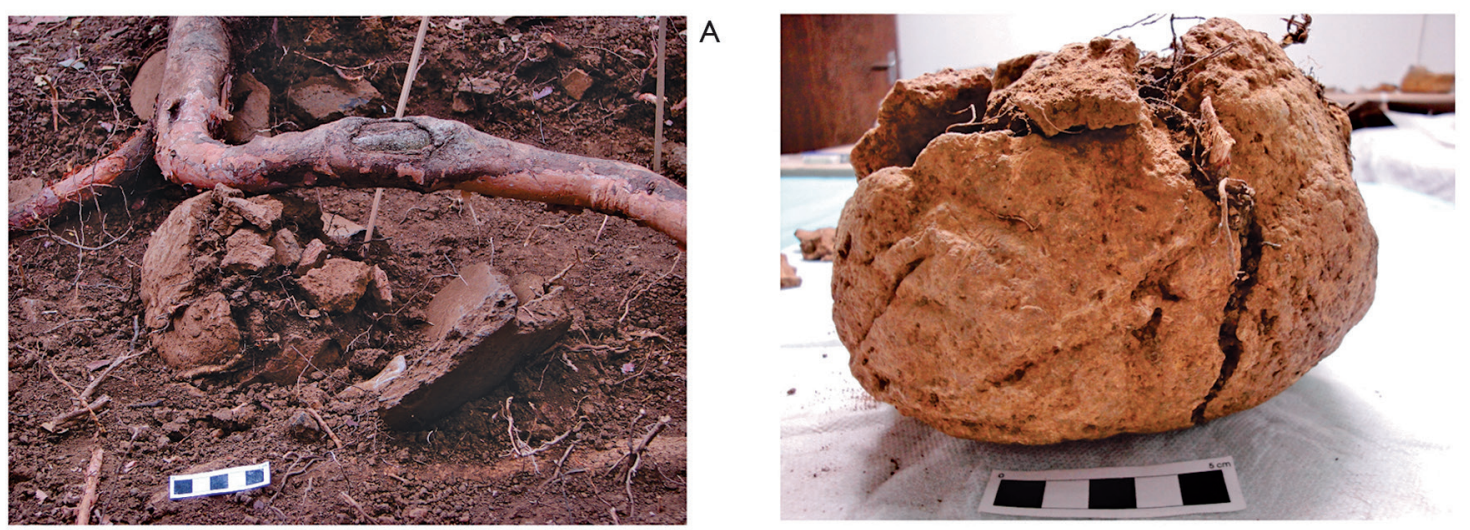

B
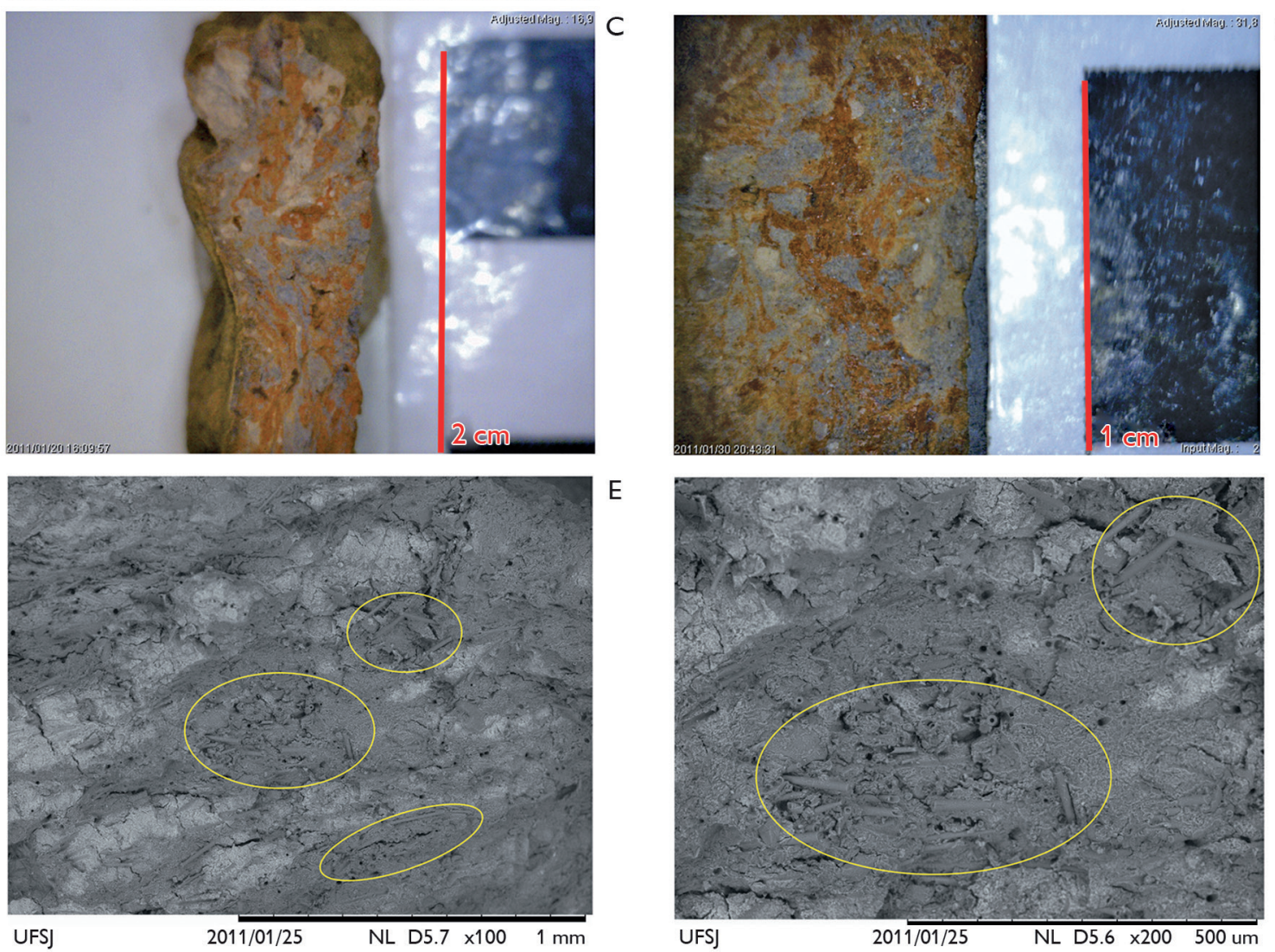

E

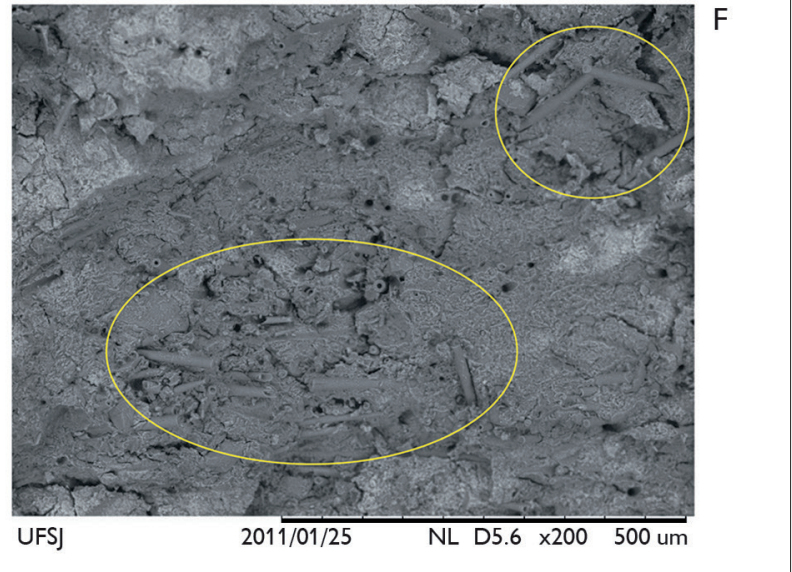

Figura 4. Registro feito em campo e laboratório referente a material coletado no sítio Vereda III: A) 'bolota' de argila não queimada, evidenciada in situ, parcialmente danificada por raiz; B) 'bolota' de argila não queimada - visualização da parte preservada. Registro feito com microscópio ótico referente a material coletado no sítio Vereda III: C) fragmento da 'bolota' de argila não queimada - observar a mistura de dois tipos de argila (vermelho e cinza) (aumento de 17x); D) fragmento de 'bolota' de argila não queimada - observar a mistura de dois tipos de argila (vermelho e cinza) (aumento de 32x). Registro feito com microscopia eletrônica de varredura, referente a material coletado no sítio Vereda III: E) os 'tubos' compridos correspondem às espículas - observar a concentração de espículas na argila de cor escura, que corresponde à argila cinza (aumento de 100x); F) detalhe da concentração de espículas ('tubos') na argila de cor escura, que corresponde à argila cinza (aumento de 200x). Escalas: 5 cm (A e B). Fotos: Rogério Tobias Jr. (A); Igor Rodrigues (B, C e D); Departamento de Engenharia Mecânica da UFS) (E e F). 
Ademais, a homogeneização poderia contribuir para outras "características de performance" (Schiffer; Skibo, 1997), tais como porosidade, resistência, entre outras apresentadas por diversos autores (Moraes, 1944; Machado, 2005 2006; Volkmer-Ribeiro; Viana, 2006; Natalio et al., 2015).

Desse modo, acredita-se que a diferença de proporção de espículas entre os tipos de pasta A e B pode ser compreendida como resultado de conscientes escolhas tecnológicas (Lemonnier, 1992) na mistura de argila cinza e argila vermelha para o preparo desses dois tipos de pastas, isto é, mais argila com espículas para o tipo A e menos argila com espículas para o tipo B. Uma vez que a 'bolota', testemunho de receita de produção de pastas, apresenta cacos moídos pequenos e muito cauixi, é possível que seja representativa do tipo de pasta A. Em todo caso, trata-se de uma boa categoria de vestígio arqueológico para pensar o processo de produção dos tipos de pastas A e B: útil para refletir sobre a intencionalidade na mistura proporcional de argilas diferentes.

Com relação às espécies de esponjas dulcícolas, foram identificadas espículas correspondentes a cinco espécies no material arqueológico: Heterorotula fistula (Volkmer-Ribeiro; Motta, 1995), Radiospongilla amazonensis (Volkmer-Ribeiro; Maciel, 1983), Dosilia pydanieli (VolkmerRibeiro, 1992), Trochospongilla variabilis (Bonetto; Ezcurra de Drago, 1973) e Metania spinata (Carter, 1881) (Figura 5). Essas espécies são típicas e caracterizam lagoas do bioma cerrado, conforme Machado et al. (2014), correspondendo às mesmas encontradas nos depósitos estudados em João Pinheiro, Minas Gerais, datados entre 28 mil e 3 mil AP (Almeida et al., 2009), e nos depósitos na região do Triângulo Mineiro, não datados, mas possivelmente antigos, em função das características ambientais necessárias para a proliferação das esponjas (Volkmer-Ribeiro; Motta, 1995; Volkmer-Ribeiro et al., 1998). Destaca-se que, nos supramencionados trabalhos, as espículas ocorrem na forma de jazidas com argila e areia, associadas ou não aos espongilitos.

Até o momento, não há datações para o sítio arqueológico Vereda III. No entanto, tendo em vista que o material de lá está associado à tradição Aratu-Sapucaí (Neves et al., 2004; Rodrigues, 2011) e que as datas disponíveis para sítios dessa tradição não ultrapassam 1200 AP, conforme revisão de datas realizada por Fernandes (2011), constata-se que o período de vivência dos grupos ceramistas conhecido é posterior ao período de deposição dos sedimentos contendo as espículas de esponjas identificadas.

Como visto, a identificação de espécies de esponjas típicas em jazidas de lagoas do Cerrado, presentes somente na argila cinza que compõe a 'bolota' de argila arqueológica, corrobora a ideia de exploração de uma jazida com espículas, ao invés de coleta de esponjas, processamento e adição na pasta. Ressalta-se que, através de análises específicas, foram observadas espículas inteiras, ou seja, não trituradas. Ademais, a coloração cinza da

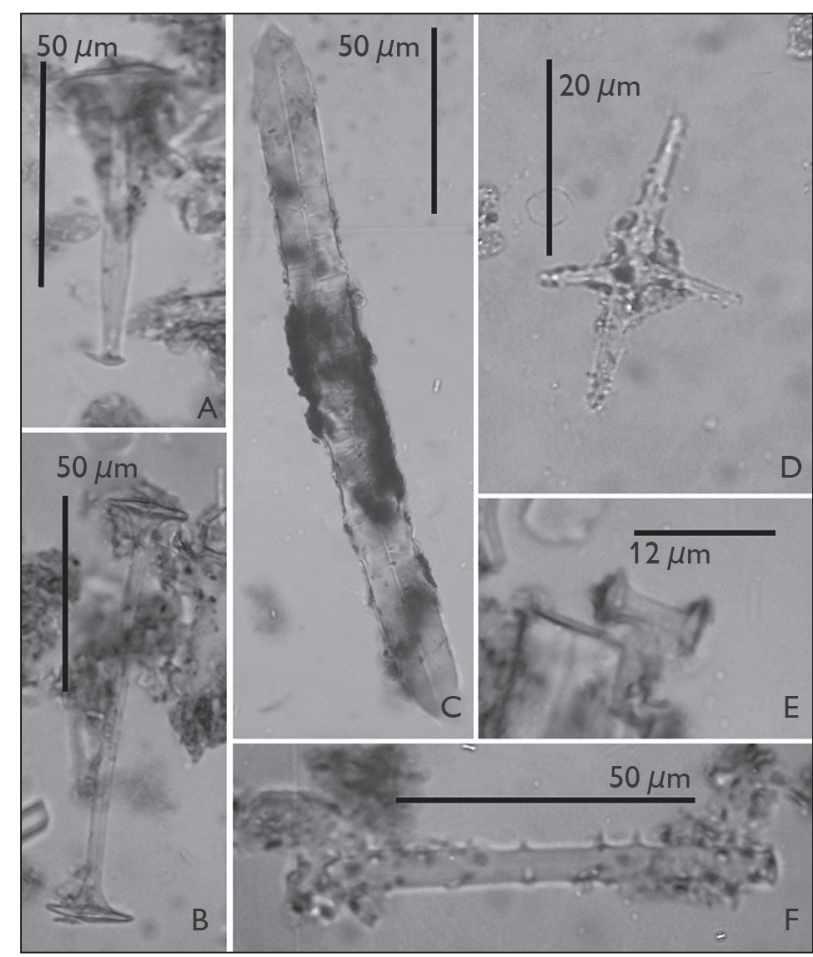

Figura 5. Fotos ao microscópio ótico das espículas encontradas nas amostras de cerâmica do sítio Vereda III: A) gemosclera de Metania spinata; B) gemosclera longa de Heterorotula fistula; C) megasclera de Heterorotula fistula; D) microsclera de Dosilia pydanieli; E) gemosclera de Trochospongilla variabilis; F) gemosclera de Radiospongilla amazonensis. Fotos e composição da imagem: Vanessa de Souza Machado. 
argila com espículas identificada na 'bolota' assemelha-se àquela dos sedimentos contendo espículas nas jazidas descritas por Volkmer-Ribeiro e Motta (1995), na região do Triângulo Mineiro, convergindo também para a hipótese de exploração de uma jazida com espículas.

Portanto, por meio da visualização de espículas inteiras, da correspondência entre as suas espécies presentes nos depósitos conhecidos e no material arqueológico, de localização delas somente na argila cinza, em período que antecede as datas disponíveis para a tradição Aratu-Sapucaí, acredita-se que a exploração de sedimentos com espículas explica melhor a presença de cauixi no material cerâmico do sítio Vereda III. É sabido que a região da Área de Proteção Ambiental (APA) Carste de Lagoa Santa, local em que o referido sítio está situado, é repleta de lagoas e brejos. Todavia, até o momento, não há jazidas com espículas já identificadas e estudadas na região em questão, para comparação de espécies e comprovação. Isso deverá ser realizado futuramente. Em todo caso, a coleta de matéria-prima para a produção oleira em depósitos lacustres é algo comum, além de mencionado em obras de referência para o estudo de cerâmica (Shepard, 1985; Rye, 1981; Rice, 1987).

\section{CAUIXI EM CERÂMICA ARQUEOLÓGICA NA REGIÃO DE LAGOA SANTA, MINAS GERAIS}

No decênio de 1970, foi realizado um estudo preliminar sobre cerâmicas arqueológicas de 29 sítios da região de Lagoa Santa, indicando semelhanças do material com a tradição Aratu-Sapucaí (Junqueira; Malta, 1978). Neste estudo, não foi identificado o cauixi, porém, no material de três sítios, foi observado amianto como antiplástico, elemento não identificado na cerâmica do sítio Vereda III. Além da referida publicação de Junqueira e Malta (1978), é desconhecida qualquer outra menção ao amianto como antiplástico em cerâmicas arqueológicas encontradas no Brasil, cabendo lembrar que, na época de sua publicação (1978), o cauixi era basicamente reconhecido apenas em cerâmicas arqueológicas amazônicas. Diante disso, realizou-se uma pequena análise em um total de 52 fragmentos cerâmicos dos seguintes sítios: Pastinho (11 fragmentos), situado em Lagoa Santa; Jaguara (15 fragmentos) e Santo Antônio do Mocambo (dez fragmentos), localizados em Matozinhos; fazenda Santa Margarida (16 fragmentos), localizada em Jaboticatubas.

A análise consistiu basicamente na observação dos tipos de antiplásticos/temperos contidos nas peças, através do estereoscópio binocular, com aumento de 40x, e com microscópio ótico. Como o material foi estudado anteriormente, aproveitaram-se os fragmentos analisados e separados. O objetivo não foi realizar uma reanálise de todo material, mas, sim, verificar o que foi identificado como amianto, pois na referida publicação de Junqueira e Malta (1978) não estão descritos os equipamentos e procedimentos realizados para sua identificação.

No material cerâmico do sítio Pastinho, Junqueira e Malta (1978, p. 129) observaram "incidências de amianto". Com relação aos antiplásticos identificados no material do sítio Jaguara, os autores afirmam que "há ainda o amianto que está desassociado da rocha, seus filamentos agulhados estão soltos dentro da pasta e curiosamente todos voltados num só sentido" (Junqueira; Malta, 1978, p. 131). Nas cerâmicas do sítio fazenda Santa Margarida, o amianto ocorre em "altas incidências" (Junqueira; Malta, 1978, p. 126). No sítio Santo Antônio do Mocambo, por sua vez, não foi identificado amianto, somente "quartzo rolado em pouca proporção" (Junqueira; Malta, 1978, p. 134). Considerando que as cerâmicas com cauixi do sítio Vereda III também apresentam pouco quartzo como antiplástico (Rodrigues, 2011), selecionou-se o material do sítio Santo Antônio do Mocambo para averiguação.

Ao invés de amianto, no material dos sítios Pastinho, Jaguara e Santo Antônio do Mocambo, identificou-se a presença de cauixi em grande quantidade, demonstrando que a existência desse elemento no material do sítio Vereda III não corresponde a um fato isolado na região de Lagoa Santa. Já no material do sítio fazenda Santa Margarida 
observou-se a presença do caraipé $^{8}$, registrado pela primeira vez em cerâmica arqueológica na região central de Minas Gerais ${ }^{9}$ (Figura 6). O amianto descrito por Junqueira e Malta (1978) na cerâmica dos sítios Pastinho e Jaguara, portanto, corresponde ao cauixi.

Com relação ao material do sítio fazenda Santa Margarida, acredita-se que o amianto também foi confundido, mas não com o cauixi, e, sim, com caraipé. Talvez isso explique a diferença percebida pelos autores entre as concentrações de 'amianto' no material desse sítio e as dos outros dois, pois, se na cerâmica dos sítios Pastinho e Jaguara o 'amianto' ocorre em incidências e solto na pasta, no material do sítio fazenda Santa Margarida ele aparece em 'altas incidências'. Como dito, foram analisados materiais

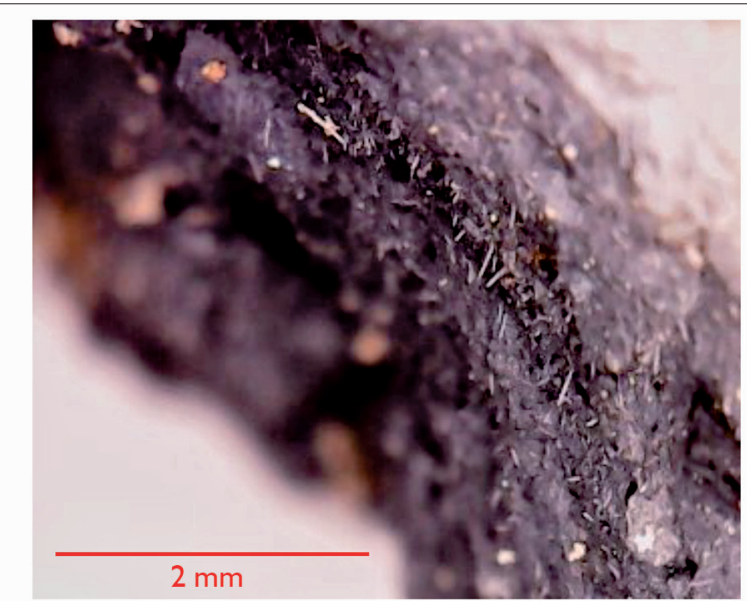

A

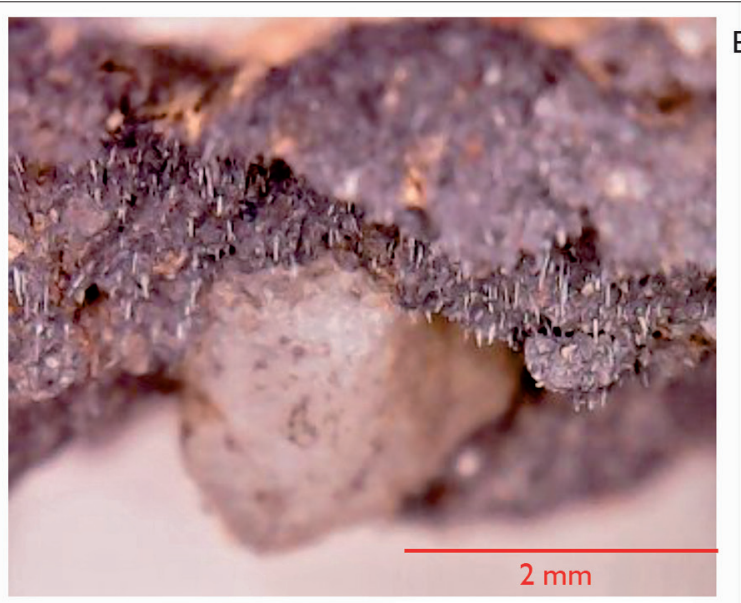

B

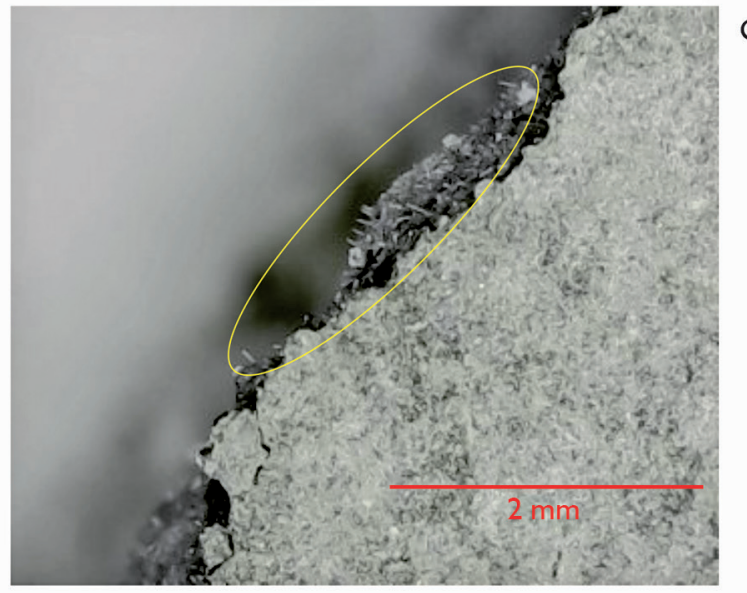

C

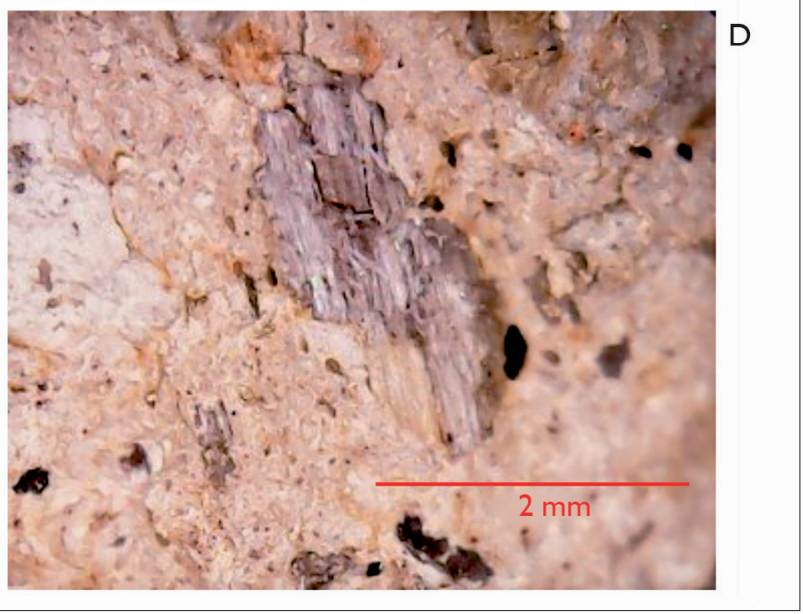

Figura 6. Registro feito com microscópio ótico: A) cauixi identificado no material cerâmico do sítio arqueológico Jaguara (Matozinhos, Minas Gerais); B) cauixi identificado no material cerâmico do sítio arqueológico Pastinho (Santa Lagoa, Minas Gerais); C) cauixi identificado no material cerâmico do sítio arqueológico Santo Antônio do Mocambo (Matozinhos, Minas Gerais); D) caraipé identificado no material cerâmico do sítio arqueológico fazenda Santa Margarida (Jaboticatubas, Minas Gerais). Os pequenos 'fios' em A, B e C correspondem às espículas. Observar o quartzo rolado ao fundo em B. Fotos: Elber Glória.

8 Caraipé, ou cariapé, é um tempero que resulta de cinzas obtidas pela queima do córtex de árvores ricas em sílica, do gênero Licania, muito comum na Amazônia e no Brasil Central (Mendonça de Souza, 1997; Carneiro, 2009).

9 A presença de caraipé em cerâmicas da tradição Aratu-Sapucaí foi observada no Triângulo Mineiro (Chymz et al., 2009), assim como em Goiás, Mato Grosso e Tocantins (Schmitz et al., 1982; Robrahn-González, 1996; Oliveira, 2005; Rodrigues, 2011).

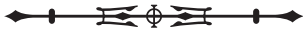


deste sítio que já tinham sido analisados por Junqueira e Malta (1978). Do total de 16 fragmentos selecionados, observou-se a presença do caraipé em metade da amostra, sendo que, na outra metade, observou-se somente o caco moído. Ao que tudo indica, tanto a espícula quanto o aglomerado de 'tubos' silicosos, que formam um fragmento de caraipé, foram interpretados como 'amianto'. Até no material cerâmico em que ele não foi observado, como exemplificado através das amostras do sítio Santo Antônio do Mocambo, há cauixi. Seja qual for o motivo da não identificação de cauixi e caraipé, e de sua confusão com o amianto, esse fato indica a necessidade de revisão do material cerâmico arqueológico da região de Lagoa Santa, Minas Gerais, de modo análogo ao constatado por Oliveira (2014) sobre a necessidade de revisão do material cerâmico dos sítios da fase Aruanã, tradição Uru, na região do rio Vermelho, em Goiás.

\section{CONSIDERAÇÕES FINAIS}

Os resultados apresentados neste artigo possibilitam diversas reflexões. A identificação da mistura de argilas no registro arqueológico do sítio Vereda III por si só é relevante, além de ser raro encontrar uma 'bolota' de argila não queimada que permita visualizar essa mistura de argilas. A primeira observação de cauixi em cerâmica arqueológica de Minas Gerais, especialmente em um material associado à tradição Aratu-Sapucaí, é extremamente relevante. A identificação do caraipé na região central de Minas Gerais, embora não seja o foco do presente trabalho, é uma novidade que também merece ser destacada.

Considerando a suposição de que as tradições Aratu-Sapucaí e Uru são entendidas enquanto cerâmicas Proto-jê, isto é, estão associadas a grupos falantes do tronco linguístico Macro-jê (Schmitz et al., 1982; Brochado, 1991; Prous, 1992), as recentes identificações de cauixi em cerâmicas dessas tradições ceramistas ${ }^{10}$ indicam a necessidade de estudos interdisciplinares sobre suas coleções. No caso da tradição Aratu-Sapucaí, em particular, com ampla dispersão pelo Brasil Central e Nordeste, a descoberta da existência de cauixi, aqui apresentada, pode contribuir para ampliar o quadro descritivo e/ou fomentar uma releitura do material dessa tradição, sobretudo nos aspectos tecnológicos. Cabe lembrar que a cerâmica dessa tradição é descrita, em geral, como extremamente homogênea e simples, apresentando poucas decorações, geralmente associadas à influência de outras tradições ceramistas, como indicado por Rodrigues (2011).

As informações levantadas a partir de registros etnográficos sobre cauixi em cerâmicas indígenas mencionam unicamente a coleta de esponjas, processamento e inclusão na pasta (Willey, 1986; Lima, 1986; Barcelos Neto, 2005-2006). Os estudos realizados por VolkmerRibeiro e Viana (2006) e Volkmer-Ribeiro e Gomes (2006) sobre os materiais arqueológicos do Mato Grosso apontam também neste sentido. Por sua vez, a hipótese deste artigo sugere, com base em diversas evidências, a exploração de jazidas com espículas em Minas Gerais. Assim, apesar de a presente pesquisa focar a coleção do sítio Vereda III, juntamente com o reconhecimento do cauixi em cerâmicas de outros três sítios da região de Lagoa Santa, espera-se que a hipótese defendida possa contribuir para estudos com cerâmicas encontradas no âmbito do Cerrado, nos quais o cauixi seja observado.

Outra contribuição diz respeito à identificação de cauixi em cerâmica fora da Amazônia. Como apontou Oliveira (2014), a expressiva presença do cauixi na Amazônia, tanto no ambiente quanto nas cerâmicas arqueológicas, contribuiu para que arqueólogos, no decênio de 1990, diante da presença de espículas em cerâmicas fora da Amazônia, sempre recorressem a artifícios explicativos, tais como contatos, trocas e influências. Posteriormente, estudos interdisciplinares sobre esponjas dulcícolas fora da referida região contribuíram para uma revisão do endemismo amazônico do cauixi (Volkmer-Ribeiro; Viana, 2006). O presente artigo corrobora este ponto de vista, destacando

\footnotetext{
10 Tanto no presente estudo para a tradição Aratu-Sapucaí, quanto no estudo de Oliveira (2014) para a tradição Uru.
} 
a importância de pesquisas interdisciplinares. No caso aqui apresentado, que considera o cauixi constante da cerâmica proveniente de exploração de depósitos sedimentares com espículas cujas espécies são típicas de lagoas do Cerrado, a possível influência amazônica fica difícil de ser sustentada. Ademais, a hipótese deste artigo indica outro método de produção cerâmica com presença de cauixi.

Diferentemente da coleta de esponjas, a busca por jazidas com espículas não necessariamente implica um reconhecimento, por parte dos produtores, de que as jazidas contenham espículas de esponjas, sobretudo quando se considera que as dimensões das espículas variam de aproximadamente 160 a $12 \mu \mathrm{m}$ de comprimento. Acredita-se que a exploração das jazidas de cauixi era realizada com base no conhecimento tradicional das características específicas que o material propicia à cerâmica. Seriam as coceiras um fator determinante? Um exemplo ilustrativo, já mencionado, se dá no Triângulo Mineiro, onde os oleiros realizavam a exploração de espongilitos em função da qualidade do produto, sabendo reconhecer os depósitos pelas coceiras provocadas pelo "pó de mico" (Moraes, 1944). Em todo caso, um método é coletar esponjas para utilização de suas espículas como tempero em uma pasta argilosa. Outro método é utilizar uma fonte com qualidades específicas, ainda que esta seja misturada a outro tipo de argila. Isto leva a uma distinção fundamental nos estudos de cerâmica arqueológica: a distinção conceitual entre tempero e antiplástico.

Embora antiplástico e tempero sejam elementos não plásticos, quando possível, devem ser diferenciados em estudos arqueológicos. Tempero é fruto de acréscimo intencional na pasta argilosa, realizado pela ação humana" ${ }^{11}$, ao passo que antiplástico é um elemento que já existe naturalmente nas jazidas de argila escolhidas para a produção oleira. No presente estudo de caso, duas das três categorias de pastas discriminadas no material do sítio Vereda III podem ser entendidas como temperadas. Indiscutivelmente, os cacos moídos são temperos adicionados às pastas $A$ e $B$, em tamanho pequeno, na primeira, e tamanho grande, na segunda. Por sua vez, a presença do cauixi, considerando a hipótese deste artigo, não poderia ser vista como um tempero, o qual, neste caso, seria a argila cinza com presença natural de espículas de esponjas, que foi misturada, em diferentes proporções, com argila vermelha para a preparação dos tipos de pasta A e B, como dito. De acordo com Shepard (1985) e Rye (1981), é comum a mistura de diferentes argilas na olaria, sendo geralmente uma mais plástica e outra menos plástica. $\bigcirc$ método de produção que tempera uma pasta através da coleta e processamento de esponjas dulcícolas, portanto, é bem diferente de outro, que tempera uma pasta com um tipo de argila de qualidade específica, ainda que, ao menos teoricamente, a presença de espículas na pasta, independentemente de sua proveniência, contribua para melhorar a queima dos potes, bem como outras características já mencionadas.

Por fim, pretende-se chamar atenção para às possibilidades de identificação de cauixi em cerâmicas arqueológicas na região da província de espongilitos proposta por Volkmer-Ribeiro e Motta (1995). Isso inclui também a região do Vale do Paraíba Paulista, visto a identificação de espongilitos por Moraes (1944) no município de Caçapava.

\section{AGRADECIMENTOS}

O primeiro autor agradece à Coordenação de Aperfeiçoamento de Pessoal de Nível Superior (CAPES) e à Fundação de Amparo à Pesquisa do Estado de Minas Gerais (FAPEMIG), pelas bolsas concedidas durante a realização do mestrado, bem como ao professor André Prous, por todo apoio logístico para a realização das pesquisas de campo. Agradece também ao professor Marco Antônio Schiavon e a Willians Fernandes, da Universidade Federal de São João del-Rei (UFSJ), pela colaboração com as análises de DFRX e MEV, assim como a Sarah Hissa, Gustavo Souza e Camila Jácome, pelas críticas ao texto, e Elber Glória, pelo auxílio nas análises e nas fotografias

\footnotetext{
11 Segundo Shepard (1985, p. 25), "to temper means to add this material to clay".
} 
das cerâmicas da região de Lagoa Santa. Todos os autores agradecem aos pareceristas anônimos pelos comentários críticos à primeira versão do manuscrito, permitindo o aperfeiçoamento das discussões apresentadas.

\section{REFERÊNCIAS}

ALMEIDA, Ariana Cristina Santos; VARAJÃO, Angélica Fortes Drummond Chicarino; VARAJÃO, César Augusto Chicarino; GOMES, Newton Souza; VOLKMER-RIBEIRO, Cecília. Domínios geomorfológicos na área de ocorrência dos depósitos de espongilito da região de João Pinheiro, Minas Gerais, Brasil. Revista Escola de Minas, Ouro Preto, v. 64, n. 3, p. 299-304, jul.-set. 2011. Disponível em: <http://www.scielo.br/scielo.php?script=sci_artte $x t \&$ pid $=$ S0370-44672011000300007>. Acesso em: 15 nov. $\overline{2} 015$.

ALMEIDA, Ariana Cristina Santos; VOLKMER-RIBEIRO, Cecília; VARAJÃO, Angélica Fortes Drummond Chicarino; GOMES, Newton Souza; VARAJÃO, César Augusto Chicarino. Espículas de esponjas continentais nos sedimentos cenozóicos do Noroeste de Minas Gerais, como indicadores paleoambientais. Revista Brasileira de Paleontologia, Porto Alegre v. 12, n. 2, p. 123-138, maio-ago. 2009. Disponível em: <http://www.sbpbrasil.org/revista/edicoes/12_2/Artigo\%20 3\%20-\%20Almeida\%20et\%20al.pdf>. Acesso em: 12 jun. 2011.

BARCELOS NETO, Aristóteles. A cerâmica wauja: etnoclassificação, matérias-primas e processos técnicos. Revista do Museu de Arqueologia e Etnologia, São Paulo, n. 15-16, p. 357-370, 2005-2006.

BROCHADO, José Proenza. Um modelo ecológico de difusão da cerâmica e da agricultura no leste da América do Sul. In: SIMPÓSIO DE PRÉ-HISTÓRIA DO NORDESTE BRASILEIRO, 1., 1991, Recife. Anais... Recife: UFPE, 1991. p. 85-86.

CARNEIRO, Robert Leonard. "Cariapé": um caso de padronização de erro em Arqueologia. Revista de Arqueologia, São Paulo, v. 22, n. 1, p. 9-13, jan.-jul. 2009.

CHYMZ, Igor; SGANZERLA, Eliane Maria; VOLCOV, Jonas Elias. Considerações sobre as sequências seriadas da Tradição Aratu/ Sapucaí em Minas Gerais. In: MEGGERS, Betty (Org.). Arqueologia interpretativa: o método quantitativo para o estabelecimento de sequências cerâmicas: estudos de caso. Porto Nacional: UNITINS, 2009. p. 63-85.

CRUZ, Abílio Augusto Velho da; ALENCAR, Marques de; MEDINA, N. H.; VOLKMER-RIBEIRO, Cecilia; GATTÁS, Vera Lúcia; LUNA, Expedito José de Albuquerque. Dangerous waters: outbreak of eye lesions caused by fresh water sponge spicules. Eye, London, v. 27, n. 3, p. 398-402, Mar. 2013. Disponível em: <http://www.ncbi.nlm. nih.gov/pmc/articles/PMC3597888/>. Acesso em: 15 nov. 2015.

FERNANDES, Henry Luydy Abraham. As lâminas de machado lascadas Aratu de Piragiba-BA. 2011. 401 f. Tese (Doutorado em Antropologia) - Universidade Federal da Bahia, Salvador, 2011.
GOMES, Denise Maria Cavalcante. Cerâmica arqueológica da Amazônia: vasilhas da coleção Tapajônica MAE-USP. São Paulo: FAPESP/EDUSP/Imprensa Oficial de São Paulo, 2002.

HILBERT, Peter Paul. A cerâmica arqueológica da região de Oriximiná. Belém: Instituto de Antropologia e Etnologia do Pará, 1955. (Publicação, 9).

JUNQUEIRA, Paulo Alvarenga; MALTA, Ione Mendes. Sítios cerâmicos da região de Lagoa Santa. Arquivos do Museu de História Natural, Belo Horizonte, v. 3, p. 117-162, 1978.

LEMONNIER, Pierre. Elements for an Anthropology of Technology. Michigan: Museum of Anthropology, University of Michigan, 1992. (Anthropological Papers, 88).

LIMA, Deborah de Magalhães. A construção histórica do termo caboclo. Sobre estruturas e representações sociais no meio rural Amazônico. Novos Cadernos NAEA, Belém, v. 2, n. 2, p. 5-32, dez. 1999.

LIMA, Tania Andrade. Zooarqueologia: algumas considerações teórico-metodológicas. Dédalo, São Paulo, v. 1, p. 175-189, 1989.

LIMA, Tania Andrade. Cerâmica indígena brasileira. In: . RIBEIRO, Darcy (Ed.). Suma etnológica brasileira: tecnologia indígena. Petrópolis: Vozes, 1986. p. 172-229. v. 2.

MACHADO, Juliana Salles. O potencial interpretativo das análises tecnológicas: um exemplo amazônico. Revista do Museu de Arqueologia e Etnologia, São Paulo, n. 15-16, p. 87-111, 2005-2006.

MACHADO, O. X. B. Zoologia: espongiários (Porífera). Rio de Janeiro: Conselho nacional de Proteção aos Índios, Publ. 102, Anexo n. 5, p. 1-4, 1947.

MACHADO, Vanessa de Souza; VOLKMER-RIBEIRO, Cecilia; IANNUZZI, Roberto. Late Pleistocene climatic changes in Central Brazil indicated by freshwater sponges. International Journal of Geosciences, Irvine, v. 5, n. 8, p. 799-815, July 2014. Available in: <http://dx.doi.org/10.4236/ijg.2014.58071>. Access in: 20 Dec. 2015.

MAGALHÃES, A. O.; VOLKMER-RIBEIRO, C.; FUJIMOTO, L. B. M.; BARBOSA, M. F.; CARDOSO, J. L.; BARCELLOS, J. F. M.; SILVA, C. C.; CAMPOS, R. R.; CUNHA, M. C. F.; FREITAS-LEMOS, A. P.; DOS-SANTOS, M. C. Induction of cell migration and activation in mice by the freshwater sponge Drulia uruguayensis Bonetto \& Ezcurra de Drago, 1968 (Porifera: Metaniidae). Journal of Venemous Animals and Toxins Including Tropical Deseases, Botucatu, v. 17, n. 1, p. 66-73, 2011. Available in: < http://www.scielo.br/pdf/jvatitd/ v17n1/09.pdf>. Access in: 21 Feb. 2016.

MENDONÇA DE SOUZA, Alfredo. Dicionário de Arqueologia. [Rio de Janeiro]: ADESA, 1997.

MIGLIACIO, Maria Clara. O doméstico e o ritual: cotidiano Xaray no Alto Paraguai até o século XVI. 2006. 464 f. Tese (Doutorado em Arqueologia) - Universidade de São Paulo, São Paulo, 2006. 
MORAES, Luciano Jacques de. Espongilitos no Triângulo Mineiro e no Estado de São Paulo. Boletim da Faculdade de Filosofia, Ciências e Letras da USP (Geologia), São Paulo, v. 1, p. 14-21, 1944.

NATALIO, Filipe; CORRALES, Tomas P.; WANKA, Stephanie; ZASLANSKY, Paul; KAPPL, Michael; LIMA, Helena Pinto; BUTT, Hans-Jürgen; TREMEL, Wolfgang. Siliceous spicules enhance fracture-resistance and stiffness of pre-colonial Amazonian ceramics. Scientific Reports, v. 5, n. 13303, 2015. Available in: < http://www. nature.com/articles/srep13303 >. Access in: 20 Nov. 2015.

NEVES, Walter Alves; KIPNIS, Renato; ARAÚJO, Astolfo; PILÓ, Luís Beethoven; HUBBE, Mark Oliver; GONÇALVES, Daniela; GLÓRIA, Pedro T.; HUBBE, Alex C.; CASTRO DE OLIVEIRA, E.; AUTI, João Paulo Vezzani. Origens e microevolução do homem na américa: uma abordagem paleoantropológica II. Relatório de auxílio à pesquisa - FAPESP. São Paulo, 2004.

OLIVEIRA, Elisângela Regina de. Aspectos da interação cultural entre os grupos ceramistas pré-coloniais do médio curso do rio Tocantins. 2005. 104 f. Dissertação (Mestrado em Arqueologia) Universidade de São Paulo, São Paulo, 2005.

OLIVEIRA, Sérgio Daher de. Bem distante da Amazônia: o cauixi nas indústrias cerâmicas do baixo rio vermelho (Britânia/GO). 2014. 203 f. Dissertação (Mestrado em Arqueologia) - Universidade Federal de Sergipe, Laranjeiras, 2014.

OLIVEIRA, Sérgio Daher de. O cauixi na cerâmica arqueológica do Brasil Central: estudo dos sítios GO-JU-17 e GO-JU-19. 2009. 112 f. Trabalho de Conclusão de Curso (Bacharelado em Arqueologia) Pontifícia Universidade Católica de Goiás, Goiânia, 2009.

ORTON, Clive; TYERS, Paul; VINCE, Alan. Pottery in Archaeology. Cambridge: Cambridge University Press, 1997. (Cambridge Manuals in Archaeology).

PROUS, André. Arqueologia brasileira. Brasília: Editora UnB, 1992.

RICE, Prudence M. Pottery analysis: a sourcebook. Chicago: University of Chicago Press, 1987.

ROBRAHN-GONZÁLEZ, Erica Marion. Os grupos ceramistas pré-coloniais do Brasil Central: origens e desenvolvimento. 1996. 269 f. Tese (Doutorado em Arqueologia) - Universidade de São Paulo, São Paulo, 1996.

RODRIGUES, Igor Morais Mariano. Fora das grandes aldeias: a ocupação do recôndito sítio arqueológico Vereda III. 2011. 318 f. Dissertação (Mestrado em Antropologia) - Universidade Federal de Minas Gerais, Belo Horizonte, 2011.

RYE, Owen S. Pottery technology: principles and reconstruction. Washington: Taraxacum, 1981. (Manuals on Archeology, v. 4).

SCHIFFER, Michael Brian; SKIBO, James M. The explanation of artifact variability. American Antiquity, Washington, v. 62, n. 1, p. 27-50, Jan. 1997.
SCHMITZ, Pedro Ignácio; WÜST, Irmhild; COPÉ, Sílvia Moehlecke; THIES, Ürsula Madalena Elfriede. Arqueologia do Centro-Sul de Goiás: uma fronteira de horticultores indígenas no Centro do Brasil. Pesquisas, São Leopoldo, v. 33, p. 1-281, 1982.

SHEPARD, Anna Osler. Ceramics for the Archaeologist. 12th. ed. Washington: Carnegie Institution of Washington, 1985. (Publication 609).

VIANA, Sibeli Aparecida; VOLKMER-RIBEIRO, Cecilia; OLIVEIRA, Sérgio Daher de. Cauixi em cerâmica arqueológica: uma questão de escolhas culturais. Revista de Arqueologia, São Paulo, v. 24, n. 1, p. 32-51, jul. 2011.

VOLKMER-RIBEIRO, Cecilia; GOMES, Denise Maria Cavalcante. Ferraz Egreja: implicações zooarqueológicas no estudo do antiplástico cerâmico. In: VIALOU, Agueda Vilhena (Org.). Préhistória do Mato Grosso: cidade de pedra. São Paulo: EDUSP, 2006. p. 203-206. v. 2.

VOLKMER-RIBEIRO, Cecilia; VIANA, Sibeli Aparecida. Cerâmica arqueológica com cauixi. In: VIANA, Sibeli Aparecida (Coord.). Pré-História no Vale do Rio Manso/MT. Goiânia: Editora da PUC - Goiás, 2006. p. 309-328.

VOLKMER-RIBEIRO, Cecilia; LENZI, Henrique L.; ORÉFICE, Fernando; PELAJO-MACHADO, Marcelo; ALENCAR, Leandro M. de; FONSECA, Carlos F.; BATISTA, Twiggy C. A.; MANSO, Pedro P. A.; COELHO, Janice; MACHADO, Marcelo. Freshwater sponge spicules: a new agent of ocular pathology. Memórias do Instituto Oswaldo Cruz, Rio de Janeiro, v. 101, n. 8, p. 899-903, dez. 2006. Disponível em: <http://www. scielo.br/pdf/mioc/v101n8/v101n8a13.pdf>. Acesso em: 21 fev. 2016.

VOLKMER-RIBEIRO, Cecilia; PAULS, Sheila M. Esponjas de agua dulce (Porifera, Demospongiae) de Venezuela. Acta Biologica Venezuelica, Caracas, v. 20, n. 1, p. 1-28, marzo 2000.

VOLKMER-RIBEIRO, Cecilia; MOTTA, José Francisco M.; CALLEGARO, Vera Lucia M. Taxonomy and distribution of Brazilian spongillites. In: WATANABE, Yoko; FUSETANI, Nobuhiro (Ed.). Sponge sciences: multidisciplinar perspectives. Tokyo: SpringerVerlag, 1998. p. 271-278.

VOLKMER-RIBEIRO, Cecilia; MOTTA, José Francisco M. Esponjas formadoras de espongilitos em lagoas no triângulo mineiro e adjacências, com indicação de preservação de habitat. Revista Biociências, Porto Alegre, v. 3, n. 2, p. 145-169, 1995.

WILLEY, Gordon. Cerâmica. In: RIBEIRO, Berta Gleizer; RIBEIRO, Darcy (Ed.). Suma etnológica brasileira: tecnologia indígena. Petrópolis: Vozes, 1986. p. 231-281. v. 2.

WÜST, Irmild. Continuidade e mudança: para uma interpretação dos grupos pré-coloniais na bacia do rio Vermelho, Mato Grosso. 1991. 505 f. Tese (Doutorado em Arqueologia) - Universidade de São Paulo, São Paulo, 1991.

WÜST, Irmild. A cerâmica Carajá de Aruaña. Anuário de Divulgação Científica, Goiânia, ano 2, n. 2, p. 90-165, 1975 